\title{
Solubility of Plutonium (IV) Oxalate During Americium/Curium Pretreatment
}

by

T. S. Rudisill

Westinghouse Savannah River Company

Savannah River Site

Aiken, South Carolina 29808

This paper was prepared in connection with work done under the above contract number with the U.S.

Department of Energy. By acceptance of this paper, the publisher and/or recipient acknowledges the U. S.

Government's right to retain a nonexclusive, royalty-free license in and to any copyright covering this paper, along with the right to reproduce and to authorize others to reproduce all or part of the copyrighted paper. 


\section{DISCLAIMER}

This report was prepared as an account of work sponsored by an agency of the United States Government. Neither the United States Government nor any agency thereof, nor any of their employees, makes any warranty, express or implied, or assumes any legal liability or responsibility for the accuracy, completeness, or usefulness of any information, apparatus, product, or process disclosed, or represents that its use would not infringe privately owned rights. Reference herein to any specific commercial product, process, or service by trade name, trademark, manufacturer, or otherwise does not necessarily constitute or imply its endorsement, recommendation, or favoring by the United States Government or any agency thereof. The views and opinions of authors expressed herein do not necessarily state or reflect those of the United States Government or any agency thereof.

This report has been reproduced directly from the best available copy.

Available to DOE and DOE contractors from the Office of Scientific and Technical Information, P.O. Box 62, Oak Ridge, TN 37831; prices available from (615) 576-8401.

Available to the public from the National Technical Information Service, U.S. Department of Commerce, 5285 Port Royal Road, Springfield, VA 22161. 


\section{DISCLAIMER}

Portions of this document may be illegible in electronic image products. Images are produced from the best available original document. 
WSRC-TR-99-0162

Revision 0

\section{Solubility of Plutonium (IV) Oxalate During Americium/Curium Pretreatment}

Tracy S. Rudisill

June 1999

Westinghouse Savannah River Company

Building 773-A

Aiken, SC 29808 
WSRC-TR-99-0162

Revision 0

Solubility of Plutonium (IV) Oxalate During Americium/Curium Pretreatment

\section{By}

Tracy S. Rudisill

Issued: June 1999

Approvals

\begin{tabular}{lc} 
Tracy A.R udisill & $6 / 18 / 99$ \\
\hline Tracy S. Rfdisill, Author & Date \\
William Croohs III & $6 / 18 / 99$ \\
\hline Wiltiam J. Crooks, III, Technical Reviewer & Date \\
Douglas R. Melton, Technical Reviewer & $6 / 21 / 59$
\end{tabular}




\section{This page was intentionally left blank.}




\section{Table of Contents}

$\begin{array}{lll}\text { Section } & \text { Page }\end{array}$

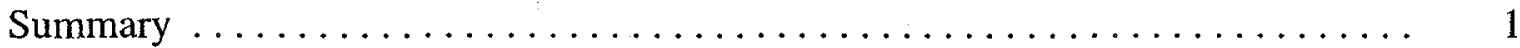

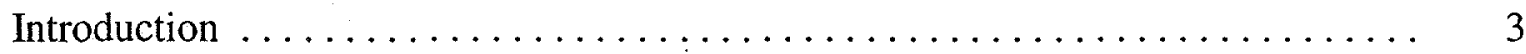

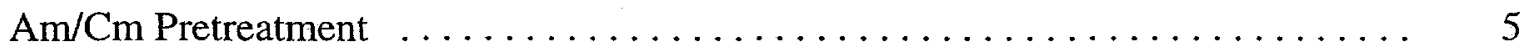

Experimental $\ldots \ldots \ldots \ldots \ldots \ldots \ldots \ldots \ldots \ldots \ldots \ldots \ldots \ldots \ldots \ldots \ldots$

Results and Discussion $\ldots \ldots \ldots \ldots \ldots \ldots \ldots \ldots \ldots \ldots \ldots$

Melter Feed Preparation $\quad \ldots \ldots \ldots \ldots \ldots \ldots \ldots \ldots \ldots \ldots \ldots \ldots \ldots \ldots \ldots$

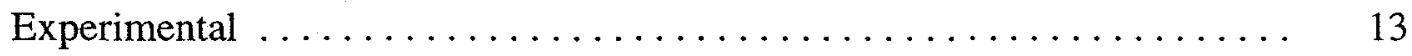

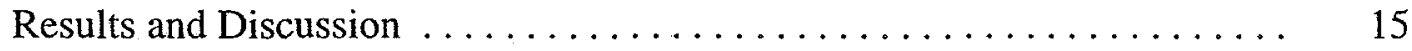

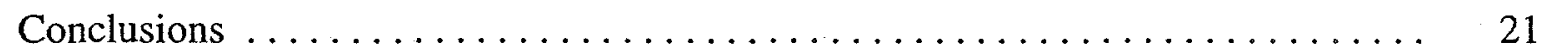

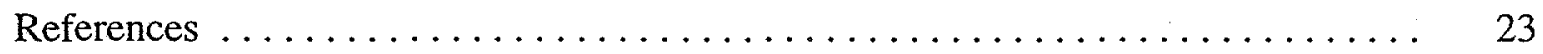

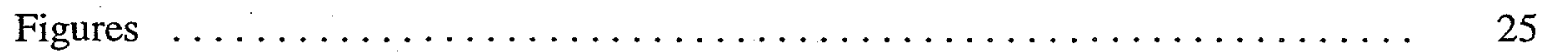

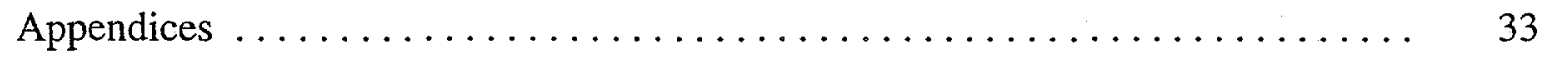




\section{List of Tables}

\section{Page}

Table $1 \quad$ Composition of Tank $17.1 \ldots \ldots \ldots \ldots \ldots \ldots \ldots \ldots \ldots \ldots \ldots \ldots \ldots$

Table 2 Oxalate Solubility Data for $\mathrm{Am} / \mathrm{Cm}$ Pretreatment $\ldots \ldots \ldots \ldots$

Table $3 \quad$ Material Balances for Am/Cm Pretreatment $\ldots \ldots \ldots \ldots \ldots \ldots \ldots .11$

Table $4 \quad$ Pretreatment Material Balance for Americium $\ldots \ldots \ldots \ldots \ldots \ldots$.

Table $5 \quad$ Composition of Pretreated Am/Cm Solution $\ldots \ldots \ldots \ldots \ldots \ldots$

Table 6 Oxalate Solubility Data for Melter Feed Preparation $\ldots \ldots \ldots \ldots$

Table $7 \quad$ Analysis of Am/Cm Surrogate Following Oxalate Precipitation $\ldots \quad \ldots \quad 17$

Table $8 \quad$ Material Balances for Melter Feed Preparation $\ldots \ldots \ldots \ldots \ldots$

Table $9 \quad$ Americium Material Balance for Melter Feed Preparation $\ldots \ldots .20$

\section{List of Figures}

Figure $1 \quad$ Am/Cm Pretreatment in F-Canyon $\ldots \ldots \ldots \ldots \ldots \ldots \ldots$

Figure $2 \quad$ Solubility of Plutonium (IV) Oxalate $\ldots \ldots \ldots \ldots \ldots \ldots \ldots$

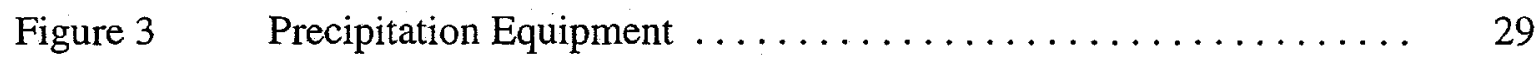

Figure $4 \quad$ Solubility of Lanthanide Oxalates $\ldots \ldots \ldots \ldots \ldots \ldots \ldots \ldots$

\section{List of Appendices}

Appendix A Preparation of Simulated Solutions $\ldots \ldots \ldots \ldots \ldots \ldots \ldots \ldots$

Appendix B Reagent Addition and Removal During Solubility Experiments . . . 35 
WSRC-TR-99-00162

Revision 0

\title{
Solubility of Plutonium (IV) Oxalate During Americium/Curium Pretreatment
}

\author{
Tracy S. Rudisill \\ Westinghouse Savannah River Company \\ Building 773-A \\ Aiken, SC 29808
}

\section{Summary}

Approximately $15,000 \mathrm{~L}$ of solution containing isotopes of americium and curium $(\mathrm{Am} / \mathrm{Cm})$ will undergo stabilization by vitrification at the Savannah River Site (SRS). Prior to vitrification, an in-tank pretreatment will be used to remove metal impurities from the solution using an oxalate precipitation process. Material balance calculations for this process, based on solubility data in pure nitric acid, predict approximately $80 \%$ of the plutonium in the solution will be lost to waste. Due to the uncertainty associated with the plutonium losses during processing, solubility experiments were performed to measure the recovery of plutonium during pretreatment and a subsequent precipitation process to prepare a slurry feed for a batch melter. A good estimate of the plutonium content of the glass is required for planning the shipment of the vitrified $\mathrm{Am} / \mathrm{Cm}$ product to Oak Ridge National Laboratory (ORNL).

The plutonium solubility in the oxalate precipitation supernate during pretreatment was 10 $\mu \mathrm{g} / \mathrm{mL}$ at $35^{\circ} \mathrm{C}$. In two subsequent washes with a $0.25 \mathrm{M}$ oxalic acid $/ 0.5 \mathrm{M}$ nitric acid solution, the solubility dropped to less than $5 \mu \mathrm{g} / \mathrm{mL}$. During the precipitation and washing steps, lanthanide fission products in the solution were mostly insoluble. Uranium, and alkali, alkaline earth, and transition metal impurities were soluble as expected. An elemental material balance for plutonium showed that greater than $94 \%$ of the plutonium was recovered in the dissolved precipitate. The recovery of the lanthanide elements was generally $94 \%$ or higher except for the more soluble lanthanum. The recovery of soluble metal impurities from the precipitate slurry ranged from 15 to $22 \%$. Theoretically, $16 \%$ of the soluble oxalates should have been present in the dissolved slurry based on the dilution effects and volumes of supernate and wash solutions removed. A trace level material balance showed greater than $97 \%$ recovery of americium-241 (from the beta decay of plutonium-241) in the dissolved precipitate, a value consistent with the recovery of europium, the americium surrogate.

In a subsequent experiment, the plutonium solubility following an oxalate precipitation to simulate the preparation of a slurry feed for a batch melter was $21 \mu \mathrm{g} / \mathrm{mL}$ at $35^{\circ} \mathrm{C}$. The increase in solubility compared to the value measured during the pretreatment experiment was attributed to the increased nitrate concentration and ensuing increase in plutonium complexation. The solubility of the plutonium following a precipitant wash with $0.1 \mathrm{M}$ oxalic acid was unchanged. The recovery of plutonium from the precipitate slurry was greater than $97 \%$ allowing an 
estimation that approximately $92 \%$ of the plutonium in Tank 17.1 will report to the glass. The behavior of the lanthanides and soluble metal impurities was consistent with the behavior seen during the pretreatment experiment. A trace level material balance showed that $99.9 \%$ of the americium was recovered from the precipitate slurry. The overall recovery of americium from the pretreatment and feed preparation processes was greater than $97 \%$, which was consistent with the measured recovery of the europium surrogate. 


\section{Introduction}

Approximately 15,000 L of solution containing isotopes of $\mathrm{Am} / \mathrm{Cm}$ are currently stored in F-Canyon Tank 17.1 at the SRS. These isotopes were recovered during plutonium-242 production campaigns in the mid and late 1970's. The continued storage of this solution was identified as an item of urgent concern in the Defense Nuclear Facility Safety Board's Recommendation 94-1.[1] To address this concern, SRS is planning to stabilize the $\mathrm{Am} / \mathrm{Cm}$ in a strontium aluminoborosilicate glass. The Multi-Purpose Processing Facility (MPPF) in F-Canyon will be used for the vitrification process. Pretreatment operations will be performed in canyon vessels to separate the actinides and lanthanides from alkali, alkaline earth, and transition metal impurities prior to vitrification.

The pretreatment operations for the $\mathrm{Am} / \mathrm{Cm}$ program include adjusting the nitric acid concentration of the solution to less than $1 \mathrm{M}$, precipitating the actinides and lanthanides as oxalates, washing the soluble metallic impurities from the precipitate slurry, solubilizing the precipitate, and concentrating the solution prior to vitrification (see Figure 1). Material balances performed for these operations predict that approximately $80 \%$ of the plutonium in the $\mathrm{Am} / \mathrm{Cm}$ solution will be lost to waste streams during the pretreatment operations. This value was calculated based on the solubility of plutonium (IV) oxalate in IM nitric acid solution.[2] The coprecipitation effects of other actinides and the lanthanides were ignored.

Due to the uncertainty associated with the plutonium losses during the pretreatment operations, solubility experiments were performed to measure the recovery during this process. A good estimate of the plutonium recovery is required for planning the shipment of the vitrified $\mathrm{Am} / \mathrm{Cm}$ product to ORNL. The actual recovery of plutonium could potentially impact the glass inventory in a shipping cask due to limitations on the total curies of plutonium. If the shipping cask contains less than 20 curies of plutonium, the shipment is exempt from most packaging and transportation requirements specified in the Code of Federal Regulations which are normally associated with fissile material.[3]

An additional solubility experiment was also performed to support the $\mathrm{Am} / \mathrm{Cm}$ vitrification flowsheet under development for an induction heated, cylindrical melter. The batch flowsheet being developed for this melter utilizes an oxalate slurry as the feed. Following concentration of the $\mathrm{Am} / \mathrm{Cm}$ solution, the feed to the vitrification process is denitrated with formic acid to adjust the nitric acid concentration to less than $1 \mathrm{M}$. Small volumes of solution (25 liters) are transferred to the MPPF and an oxalate precipitation performed using the amount of solution (approximately 7 liters) required to fabricate a single can of glass. The precipitation is performed using nominally $0.9 \mathrm{M}$ oxalic acid, an excess oxalate concentration of $0.3 \mathrm{M}$, a digestion period of $30 \mathrm{~min}$, and a single wash using $0.1 \mathrm{M}$ oxalic acid. To simulate the feed preparation process, a simulated $\mathrm{Am} / \mathrm{Cm}$ solution was prepared based on the pretreatment material balance and plutonium solubility data from the simulated pretreatment experiment. An oxalate precipitation was then performed using the same conditions proposed for the batch flowsheet. Samples of the precipitation supernate and wash solution were analyzed to determine the solubility of plutonium and other elements of interest. 
WSRC-TR-99-00162

Revision 0

\section{This page was intentionally left blank.}




\section{Am/Cm Pretreatment}

\section{Experimental}

A laboratory-scale demonstration of the $\mathrm{Am} / \mathrm{Cm}$ pretreatment process was performed using a simulated solution with an elemental concentration representative of Tank 17.1. The composition of the simulant was based on the analysis of samples from the tank in 1993 and 1998. The most recent analyses were used to prepare the simulant for elements analyzed at both times. A summary of the element masses and concentrations, based on a solution volume of $15,000 \mathrm{~L}$, is presented in Table 1.

Table 1 Composition of Tank 17.1

\begin{tabular}{lrc}
\hline \hline \multicolumn{1}{c}{ Element } & $\begin{array}{c}\text { Mass } \\
(\mathrm{g})\end{array}$ & $\begin{array}{c}\text { Concentration } \\
(\mathrm{g})\end{array}$ \\
\hline Americium & 9,154 & 0.610 \\
Curium & 2,381 & 0.159 \\
Plutonium & 8,916 & 0.594 \\
Uranium & 2,205 & 0.147 \\
& & \\
Lanthanum & 14,770 & 0.985 \\
Cerium & 11,610 & 0.774 \\
Praseodymium & 9,918 & 0.661 \\
Neodymium & 28,490 & 1.899 \\
Samarium & 6,753 & 0.450 \\
Europium & 1,372 & 0.091 \\
Gadolinium & 3,482 & 0.232 \\
& & \\
Aluminum & 16,410 & 1.094 \\
Calcium & 999 & 0.067 \\
Chromium & 5,909 & 0.394 \\
Iron & 72,800 & 4.853 \\
Potassium & 3,255 & 0.217 \\
Manganese & 3,641 & 0.243 \\
Sodium & 8,242 & 0.549 \\
Nickel & 4,326 & 0.147 \\
\hline Total & 214,633 & 14.307 \\
\hline a) Solution & &
\end{tabular}

(a) Solution concentrations based on a $15,000 \mathrm{~L}$ volume

Elements with a total mass less than approximately $1000 \mathrm{~g}$ were not included in the simulant. During preparation of the simulant, equal molar concentrations of the corresponding lanthanides (europium and gadolinium) were used as surrogates for the $\mathrm{Am} / \mathrm{Cm}$. The presence of chromium in Tank 17.1 was not simulated to prevent the addition of hazardous material to the surrogate solution. An equal molar concentrations of iron was added to simulated the solution chemistry of 
chromium during the pretreatment process. The use of europium and gadolinium as surrogates for $\mathrm{Am} / \mathrm{Cm}$ and the substitution of iron for chromium is consistent with the preparation of surrogate solutions used during the $\mathrm{Am} / \mathrm{Cm}$ pretreatment development program.[4]

The surrogate solution was prepared by initially dissolving the target amounts of the nonradioactive nitrate salts in $1 \mathrm{M}$ nitric acid, transferring the solution to a $1 \mathrm{~L}$ volumetric flask, and filling the flask with $1 \mathrm{M}$ nitric acid. A summary of the starting materials used to prepare the solution, the target and actual masses of reagents, and the final concentrations is provided in Appendix A. The surrogate solution used in the solubility experiment was then prepared by adding the target amount of uranyl nitrate hexahydrate (UNH) and a measured aliquot of a nitrate solution containing $34 \mathrm{~g} / \mathrm{L}$ plutonium to $500 \mathrm{~mL}$ of the nonradioactive solution. The concentrations of uranium and plutonium in the surrogate are summarized in Appendix A.

The pretreatment solubility experiment was performed using a $1 \mathrm{~L}$, three-neck flask shown schematically on Figure 3. The bottom of the flask was slightly flattened to facilitate heating on a hot plate. Agitation was provided by a magnetic stirring bar. A graduated addition funnel with stopcock was used to add acid solutions at a controlled rate during the pretreatment process. The temperature of the precipitation vessel was monitored by inserting a calibrated thermometer into the flask. The oxalate precipitation was performed by adding a $250 \mathrm{~mL}$ aliquot of the simulated Tank 17.1 solution to the flask, heating the solution to $60^{\circ} \mathrm{C}$, and adding $150 \mathrm{~mL}$ of $0.9 \mathrm{M}$ oxalic acid over approximately $15 \mathrm{~min}$. The excess oxalic acid concentration was $0.3 \mathrm{M}$ based on the prepared concentrations and complete precipitation of the lanthanide elements and plutonium. During the oxalic acid addition, the solution was stirred using the magnetic stirring bar. Once the oxalic acid addition was complete, the flask contents were cooled to $45^{\circ} \mathrm{C}$ (with continual stirring) and digested for $4 \mathrm{hr}$. Following the digestion period, the flask contents were cooled to $35^{\circ} \mathrm{C}$ and allowed to settle for $1 \mathrm{hr}$. The solution was held at $35^{\circ} \mathrm{C}$ to simulate radiolytic heating during the pretreatment of the actual material. Three $9.4 \mathrm{~mL}$ samples of the precipitation supernate were removed from the flask using a $10 \mathrm{~mL}$ disposable syringe. The solution was expelled through an $0.45 \mu \mathrm{m}$ filter disk into a small plastic sample bottle.

Following removal of the samples, a volume of supernate approximately equal to the precipitant volume (minus the sample volume) was removed from the flask. The solution was transferred using a dip leg inserted into the flask which was connected to a receipt bottle under vacuum (see Figure 3). The depth of the dip leg was calibrated to leave approximately $250 \mathrm{~mL}$ of solution in the flask. After cooling overnight to $19^{\circ} \mathrm{C}$, a fine precipitate was seen in the sample bottles and the receipt bottle. The precipitate in the sample bottles was dissolved by pipetting a $2 \mathrm{~mL}$ aliquot of concentrated (15.7M) nitric acid into each bottle. Concentration errors associated with changes in the density of the sample as a function of temperature were ignored due to the much larger uncertainties associated with the trace metal and radiochemical analyses. Three additional samples of the precipitation supernate were removed from the receipt bottle at $19^{\circ} \mathrm{C}$ using the same sampling procedure to allow a comparison with the solubility data at $35^{\circ} \mathrm{C}$. 
In preparation for the first washing step, the precipitate and remaining supernate were stirred and heated to $35^{\circ} \mathrm{C}$. The precipitate was then washed using a $250 \mathrm{~mL}$ aliquot of $0.25 \mathrm{M}$ oxalic acid/0.5M nitric acid solution. The wash solution was added using the addition funnel over approximately $15 \mathrm{~min}$. Once the addition was complete, the solution was stirred for an additional $15 \mathrm{~min}$ and allowed to settle for $1 \mathrm{hr}$. Three $9.4 \mathrm{~mL}$ samples of the wash solution supernate were removed from the flask using the sampling procedure discussed above. After sampling, supernate was transferred from the flask using the dip leg leaving an approximate $250 \mathrm{~mL}$ volume in the flask. After cooling overnight to $18.5^{\circ} \mathrm{C}$, a fine precipitate was seen in the sample bottles and supernate removed from the precipitation vessel. The precipitate in the sample bottles was dissolved by pipetting a $2 \mathrm{~mL}$ aliquot of $15.7 \mathrm{M}$ nitric acid into each bottle. A second set of samples was removed from the transferred supernate (at $18.5^{\circ} \mathrm{C}$ ) to allow a . comparison with the solubility data at $35^{\circ} \mathrm{C}$.

The precipitate wash procedure was repeated a second time following the same steps discussed above. Three $9.4 \mathrm{~mL}$ samples of supernate were removed prior to transferring solution from the flask. After cooling overnight to $16.5^{\circ} \mathrm{C}$, precipitates were present in both the sample bottles and transferred supernate. The precipitate in the sample bottles was dissolved by pipetting a $2 \mathrm{~mL}$ aliquot of concentrated nitric acid into each bottle. Three additional samples of the transferred supernate were removed at $16.5^{\circ} \mathrm{C}$ to allow a comparison with the solubility data at $35^{\circ} \mathrm{C}$. The precipitate slurry remaining in the flask was dissolved in nominally $8 \mathrm{M}$ nitric acid by adding a $250 \mathrm{~mL}$ aliquot of $15.7 \mathrm{M}$ nitric acid over approximately $45 \mathrm{~min}$ and heating at $65^{\circ} \mathrm{C}$ for $30 \mathrm{~min}$. After cooling overnight to $18^{\circ} \mathrm{C}$, three $9.4 \mathrm{~mL}$ samples of the solution were removed for analysis. No solids were present in the flask. The final volume of solution following sample removal was $452 \mathrm{~mL}$. A summary of the solution volumes added and removed from the precipitation flask during the pretreatment process is provided in Appendix B.

\section{$\underline{\text { Results and Discussion }}$}

The analytical results for the pretreatment solubility experiment are summarized in Table 2 . The concentrations given in the table are the average results from the analysis of triplicate samples taken at each sampling point during the pretreatment experiment. Plutonium analyses were performed by liquid scintillation counting using a gamma scan to correct the total alpha activity for americium-241. The lanthanide elements, aluminum, calcium, iron, manganese, sodium, and nickel were determined by induction-coupled plasma emission spectroscopy (ICP-ES). Potassium was determined by atomic absorption spectroscopy (AAS) and uranium by pulsed laser fluorometry. The data reported in Table 2 reflect the necessary dilutions made to dissolve the solids precipitated during sample cooling.

The concentrations for the Tank 17.1 simulant listed in Table 2 include values for each element calculated from the mass of the starting materials (see Appendix A) and the experimentally measured values. The difference between the two concentrations was generally less than $10 \%$. The largest differences were associated with the hydrated nitrate salts (i.e. lanthanide elements and iron) and were likely biased low due to the absorption of moisture by the salts. The measured concentrations were used in all subsequent calculations presented in Table 2 . 
The solubility of the plutonium (IV) oxalate in the precipitation supernate was $10 \mu \mathrm{g} / \mathrm{mL}$ at $35^{\circ} \mathrm{C}$. The corresponding solubility in $0.63 \mathrm{M}$ nitric acid with $0.3 \mathrm{M}$ excess oxalic acid can be estimated from Figure 2 as approximately $110 \mu \mathrm{g} / \mathrm{mL}$ at $26.5^{\circ} \mathrm{C}$. In addition to the temperature effect, the large decrease in solubility can be attributed to coprecipitation with the lanthanide elements. The ionic radii of the lanthanide elements and plutonium are quite similar.[5] Random substitution of these elements in the oxalate crystal lattice will occur reducing the solubility normally seen for plutonium (IV) oxalate in pure nitric acid solution. Plutonium (IV) coprecipitates quite completely with lanthanum oxalate from approximately $0.1 \mathrm{M}$ nitric acid/ $/ 0.1 \mathrm{M}$ oxalic acid, but further increase in the oxalate concentration yields less effective coprecipitation due to the formation of soluble plutonium (IV) oxalate complexes.[2]

The solubility of the lanthanide elements given in Table 2 reflect the same general trend observed during the Am/Cm pretreatment development program;[4] although, the measured solubilities for the elements were somewhat higher. To illustrate this trend, solubility data for selected lanthanide elements from the pretreatment development program are plotted on Figure 4. From this figure, one can see that the solubility of the lanthanide elements tend to decrease with increasing atomic number. The exception to this rule is neodymium which became more soluble

Table 2 Oxalate Solubility Data for Am/Cm Pretreatment

Insoluble Oxalates

\begin{tabular}{|c|c|c|c|c|c|c|c|c|}
\hline & $\begin{array}{c}\mathrm{La} \\
(\mu \mathrm{g} / \mathrm{mL})\end{array}$ & $\begin{array}{c}\mathrm{Ce} \\
(\mu \mathrm{g} / \mathrm{mL})\end{array}$ & $\begin{array}{c}\mathrm{Pr} \\
(\mu \mathrm{g} / \mathrm{mL})\end{array}$ & $\begin{array}{c}\mathrm{Nd} \\
(\mu \mathrm{g} / \mathrm{mL}) \\
\end{array}$ & $\begin{array}{c}\mathrm{Sm} \\
(\mu \mathrm{g} / \mathrm{mL})\end{array}$ & $\begin{array}{c}\mathrm{Eu} \\
(\mu \mathrm{g} / \mathrm{mL})\end{array}$ & $\begin{array}{c}\mathrm{Gd} \\
(\mu \mathrm{g} / \mathrm{mL}) \\
\end{array}$ & $\begin{array}{c}\mathrm{Pu} \\
(\mu \mathrm{g} / \mathrm{mL})\end{array}$ \\
\hline \multicolumn{9}{|l|}{ Simulant } \\
\hline Makeup & 983 & 773 & 661 & 1900 & 451 & 463 & 326 & 200 \\
\hline Analysis & 927 & 763 & 641 & 1783 & 417 & 423 & 308 & 221 \\
\hline \multicolumn{9}{|l|}{ Supernate } \\
\hline Analysis $\left(35^{\circ} \mathrm{C}\right)$ & 145 & 51 & 23 & 45 & 9.3 & 7.3 & 6.3 & 10 \\
\hline Analysis $\left(19^{\circ} \mathrm{C}\right)$ & 98 & 26 & 8.5 & 14 & 3.4 & 1.4 & 1.8 & 0.5 \\
\hline \multicolumn{9}{|l|}{$1^{\text {st }}$ Wash } \\
\hline Analysis $\left(35^{\circ} \mathrm{C}\right)$ & 43 & 11 & 3.3 & 7.3 & 1.8 & 1.0 & 1.0 & 2.7 \\
\hline Analysis $\left(18.5^{\circ} \mathrm{C}\right)$ & 40 & 9.2 & 3.0 & 5.0 & 1.8 & 0.6 & 0.9 & 1.8 \\
\hline \multicolumn{9}{|l|}{$\underline{2}^{\text {nd }}$ Wash } \\
\hline Analysis $\left(35^{\circ} \mathrm{C}\right)$ & 16 & 5.5 & $<1.5$ & 4.4 & 1.0 & 0.7 & 0.6 & 4.0 \\
\hline Analysis $\left(16.5^{\circ} \mathrm{C}\right)$ & 14 & 3.6 & 0.5 & 2.7 & 0.8 & 0.4 & 0.5 & 3.5 \\
\hline \multicolumn{9}{|l|}{ Feed } \\
\hline Analysis & 410 & 373 & 318 & 893 & 209 & 216 & 158 & 106 \\
\hline Calculated $^{(\mathrm{a})}$ & 483 & 397 & 334 & 928 & 217 & 220 & 160 & 115 \\
\hline
\end{tabular}

(a) Calculated values assume $100 \%$ recovery. 
WSRC-TR-99-00162

Revision 0

Table 2 Continued

Soluble Oxalates

\begin{tabular}{|c|c|c|c|c|c|c|c|c|}
\hline & $\begin{array}{c}\mathrm{U} \\
(\mu \mathrm{g} / \mathrm{mL}) \\
\end{array}$ & $\begin{array}{c}\mathrm{Al} \\
(\mu \mathrm{g} / \mathrm{mL}) \\
\end{array}$ & $\begin{array}{c}\mathrm{Ca} \\
(\mu \mathrm{g} / \mathrm{mL}) \\
\end{array}$ & $\begin{array}{c}\mathrm{Fe} \\
(\mu \mathrm{g} / \mathrm{mL}) \\
\end{array}$ & $\begin{array}{c}\mathrm{K} \\
(\mu \mathrm{g} / \mathrm{mL})\end{array}$ & $\begin{array}{c}\mathrm{Mn} \\
(\mu \mathrm{g} / \mathrm{mL})\end{array}$ & $\begin{array}{c}\mathrm{Na} \\
(\mu \mathrm{g} / \mathrm{mL}) \\
\end{array}$ & $\begin{array}{c}\mathrm{Ni} \\
(\mu \mathrm{g} / \mathrm{mL}) \\
\end{array}$ \\
\hline \multicolumn{9}{|l|}{ Simulant } \\
\hline Makeup & 612 & 1094 & 67 & 5277 & 219 & 243 & 552 & 288 \\
\hline Analysis & 613 & 1041 & 64 & 5669 & 212 & 217 & 532 & 258 \\
\hline Supernate & & & & & & & & - \\
\hline Analysis $\left(35^{\circ} \mathrm{C}\right)$ & 388 & 620 & 39 & 3289 & 139 & 137 & 324 & 169 \\
\hline Analysis $\left(19^{\circ} \mathrm{C}\right)$ & 370 & 648 & 40 & 3686 & 133 & 139 & 338 & 173 \\
\hline Calculated $^{(\mathbf{b})}$ & 383 & 650 & 40 & 3543 & 132 & 136 & 333 & 162 \\
\hline \multicolumn{9}{|l|}{$1^{\text {st }}$ Wash } \\
\hline Analysis $\left(35^{\circ} \mathrm{C}\right)$ & 198 & 312 & 20 & 1698 & 68 & 70 & 164 & 87 \\
\hline Analysis $\left(18.5^{\circ} \mathrm{C}\right)$ & 183 & 332 & 22 & 1665 & 67 & 74 & 173 & 91 \\
\hline Calculated ${ }^{(b)}$ & 193 & 327 & 20 & 1781 & 67 & 68 & 167 & 81 \\
\hline \multicolumn{9}{|l|}{${\underline{2^{\text {nd }}} \text { Wash }}$} \\
\hline Analysis $\left(35^{\circ} \mathrm{C}\right)$ & 97 & 155 & 10 & 844 & 33 & 35 & 82 & 43 \\
\hline Analysis $\left(16.5^{\circ} \mathrm{C}\right)$ & 91 & 161 & 11 & 828 & 32 & 36 & 84 & 44 \\
\hline Calculated $^{(\mathrm{b})}$ & 95 & 162 & 10 & 882 & 33 & 34 & 83 & 40 \\
\hline \multicolumn{9}{|l|}{ Feed } \\
\hline Analysis & 54 & 99 & 7.9 & 423 & 17 & 18 & 44 & 23 \\
\hline Calculated $^{(\mathrm{b})}$ & 52 & 89 & 5.5 & 484 & 18 & 19 & 45 & 22 \\
\hline
\end{tabular}

(b) Calculated values assume complete solubility.

than cerium and praseodymium at lower oxalic acid concentrations. Similar behavior for neodymium was also seen in the pretreatment solubility experiment. The measured solubility for neodymium was higher than the solubility of praseodymium and approximately equal to the solubility of cerium. The increase in the solubilities of the lanthanide elements (compared to values measured during the $\mathrm{Am} / \mathrm{Cm}$ pretreatment development program) could be explained by the way the precipitation flask was heated during the solubility experiment. Using a hot plate to heat the flask from the bottom would create a temperature gradient in the flask, especially when the stirrer was off during the time the relatively small volume of precipitate was allowed to settle. The higher temperature near the bottom of the flask may have increased the solubility of these elements. The precipitation flask during the $\mathrm{Am} / \mathrm{Cm}$ pretreatment development program was totally immersed in a water batch which would maintain a more uniform temperature in the precipitate slurry. 
The effect of temperature on the oxalate solubility of the lanthanide elements and plutonium during pretreatment can be seen in Table $2 . \mathrm{A} 16^{\circ} \mathrm{C}$ decrease in temperature had a significant impact on the solubilities in the precipitation supernate, reducing the lanthanide solubilities by a factor of 1.5 to 5.2 and plutonium solubility by a factor of 20 . The effect of temperature on the oxalate solubilities was not as pronounced in the two wash solutions. This can be attributed to a decrease in the nitric acid concentration during the two washes which reduced the solubilities. The measured concentrations were also nearing or at the detection limits of the ICP-ES.

As expected, uranium and the alkali, alkaline earth, and transition metal impurities in the Tank 17.1 simulant were soluble throughout the pretreatment process. The measured concentrations in the precipitation supernate and the wash solutions can be accurately predicted by taking into account the dilution effects and the removal of the supernate and wash solutions from the precipitation flask. The calculated concentrations in Table 2 were estimated using this procedure. A decrease in temperature had no effect on the concentrations measured in the precipitation supernate or the wash solutions for these elements.

Using the concentrations given in Table 2 and the volumes of solution added and removed from the precipitation flask during the pretreatment experiment (reported in Appendix B), material balances were performed for each element in the Tank 17.1 simulant. For each element, the percentage of the mass recovered following dissolution of the oxalate precipitate and the percentages lost to the precipitation supernate and wash solutions are given in Table 3 . The material balance closure for each element, calculated as the percentage of the element in Tank 17.1 simulant, is also presented.

The material balances for the lanthanide elements and plutonium reiterate that solubility losses for these elements will be reasonably low during the pretreatment process. Losses of $\mathrm{Am} / \mathrm{Cm}$ should differ little from the losses of the europium and gadolinium surrogates used in the simulated solution. Coprecipitation of plutonium (IV) with the lanthanide and $\mathrm{Am} / \mathrm{Cm}$ oxalates will also minimize solubility losses of plutonium with greater than $94 \%$ of the element reporting to the vitrification feed solution. The plutonium recovery does not take into account transfer losses such as entrainment of oxalate solids during precipitate washes; however, the ratio of the plutonium recovery to the recovery of the lanthanides (and $\mathrm{Am} / \mathrm{Cm}$ ) should change very little. Preferential separation of plutonium from other insoluble oxalates will not occur during solution transfer operations.

The recovery of uranium and the alkali, alkaline earth, and transition metal impurities ranged from approximately 15 to $22 \%$. Based on the dilution effects and the volumes of supernate and wash solutions removed during the experiment, the theoretical recovery was $16 \%$. Of the $84 \%$ of the soluble oxalates theoretically removed during the pretreatment experiment, $37 \%$ was removed in the precipitation supernate, $32 \%$ was removed in the first wash solution, and $14 \%$ was removed in the second wash solution. The removal of metal impurities from the actual $\mathrm{Am} / \mathrm{Cm}$ solution during pretreatment operations should be close to these values assuming the additions of precipitant and wash solution and removals of supernate are proportional to the volumes used during the pretreatment experiment. 
Table 3 Material Balances for $\mathrm{Am} / \mathrm{Cm}$ Pretreatment Insoluble Oxalates

\begin{tabular}{lcccccccc}
\hline \hline & $\begin{array}{c}\mathrm{La} \\
(\%)\end{array}$ & $\begin{array}{c}\mathrm{Ce} \\
(\%)\end{array}$ & $\begin{array}{c}\mathrm{Pr} \\
(\%)\end{array}$ & $\begin{array}{c}\mathrm{Nd} \\
(\%)\end{array}$ & $\begin{array}{c}\mathrm{Sm} \\
(\%)\end{array}$ & $\begin{array}{c}\mathrm{Eu} \\
(\%)\end{array}$ & $\begin{array}{c}\mathrm{Gd} \\
(\%)\end{array}$ & $\begin{array}{c}\mathrm{Pu} \\
(\%)\end{array}$ \\
\hline Element Recovered & 84.5 & 93.8 & 97.3 & 97.8 & 98.0 & 98.6 & 98.3 & 94.3 \\
& & & & & & & & \\
& 15.5 & 6.2 & 2.7 & 2.2 & 2.0 & 1.4 & 1.7 & 5.7 \\
Element Lost & 9.2 & 4.0 & 2.2 & 1.5 & 1.3 & 1.0 & 1.2 & 2.7 \\
$\quad \begin{array}{l}\text { Precipitation Supernate } \\
1^{\text {st }} \text { Wash Solution }\end{array}$ & 4.8 & 1.5 & 0.5 & 0.4 & 0.5 & 0.2 & 0.3 & 1.3 \\
$2^{\text {nd }}$ Wash Solution & 1.6 & 0.7 & 0.0 & 0.2 & 0.2 & 0.2 & 0.2 & 1.7 \\
& & & & & & & & \\
Material Balance Closure & 100.5 & 100.1 & 97.9 & 98.3 & 98.3 & 99.6 & 99.9 & 98.0 \\
\hline & & & & & & & & \\
& & Soluble Oxalates & & & & \\
\hline \hline & $\mathrm{U}$ & $\mathrm{Al}$ & $\mathrm{Ca}$ & $\mathrm{Fe}$ & $\mathrm{K}$ & $\mathrm{Mn}$ & $\mathrm{Na}$ & $\mathrm{Ni}$ \\
& $(\%)$ & $(\%)$ & $(\%)$ & $(\%)$ & $(\%)$ & $(\%)$ & $(\%)$ & $(\%)$ \\
\hline Element Recovered & 16.6 & 18.7 & 22.0 & 15.4 & 15.3 & 15.9 & 16.3 & 16.2 \\
& & & & & & & & \\
& 83.4 & 81.3 & 78.0 & 84.6 & 84.7 & 84.1 & 83.7 & 83.8 \\
Element Lost & 36.5 & 35.8 & 33.7 & 36.7 & 38.2 & 36.7 & 36.7 & 36.4 \\
$\quad$ Precipitation Supernate & 32.6 & 31.4 & 30.2 & 33.1 & 32.3 & 32.7 & 32.4 & 32.6 \\
$\quad 1^{\text {st }}$ Wash Solution & 14.3 & 14.0 & 14.0 & 14.8 & 14.2 & 14.7 & 14.5 & 14.7 \\
$2^{\text {nd }}$ Wash Solution & & & & & & & & \\
& 102.1 & 98.1 & 107.0 & 93.1 & 101.7 & 101.5 & 97.8 & 105.6 \\
\hline Material Balance Closure & & & & & & &
\end{tabular}

Since the beta decay of plutonium-241 provides a constant in-growth of americium in weapons grade plutonium, the fate of americium during the $\mathrm{Am} / \mathrm{Cm}$ pretreatment process can be followed using a trace level material balance. The mass of americum-241 was calculated using the gamma scans for the samples taken during the pretreatment experiment. Table 4 provides a summary of the americium mass in the simulated Tank 17.1 solution and the amounts recovered and lost during the pretreatment operations. An americium material balance, presented in the table, gives the percentage of the mass recovered following dissolution of the oxalate precipitate and the percentages lost to the precipitation supernate and wash solutions. The material balance closure was $99.3 \%$ calculated as the percentage of the americium in the simulated solution. The recovery of greater than $97 \%$ of the americium in the dissolved oxalate precipitate is consistent with the recovery of europium, the surrogate for americium in the simulated solution. 
Table 4 Pretreatment Material Balance for Americium

\begin{tabular}{lcc}
\hline \hline & $\begin{array}{c}\text { Mass } \\
(\mathrm{mg})\end{array}$ & $\begin{array}{c}\text { Total } \\
(\%)\end{array}$ \\
\hline Americium in Simulant & $1.24 \times 10^{-6}$ & \\
Americium Recovered & $1.20 \times 10^{-6}$ & 97.5 \\
& & \\
Americium Lost & $3.12 \times 10^{-8}$ & 2.5 \\
Precipitation Supernate & $1.72 \times 10^{-8}$ & 1.4 \\
$1^{\text {st }}$ Wash Solution & $9.53 \times 10^{-9}$ & 0.8 \\
$2^{\text {nd }}$ Wash Solution & $4.46 \times 10^{-9}$ & 0.4 \\
Material Balance Closure & & 99.3 \\
\hline
\end{tabular}




\section{Melter Feed Preparation}

\section{$\underline{\text { Experimental }}$}

The preparation of an oxalate slurry feed for the batch vitrification flowsheet was simulated by preparing a surrogate solution based on the elemental concentrations predicted by a pretreatment material balance. A summary of the element masses and concentrations, based on a solution volume of $1,166 \mathrm{~L}$, is presented in Table 5 .

Table 5 Composition of Pretreated Am/Cm Solution

\begin{tabular}{lrc}
\hline \hline \multicolumn{1}{c}{ Element } & $\begin{array}{c}\text { Mass } \\
(\mathrm{g})\end{array}$ & $\begin{array}{c}\text { Concentration } \\
(\mathrm{g} / \mathrm{L})\end{array}$ \\
\hline Americium & 8869 & 7.61 \\
Curium & 2182 & 1.87 \\
Plutonium & 2238 & 1.92 \\
Uranium & 165 & 0.14 \\
& & \\
Lanthanum & 14668 & 12.58 \\
Cerium & 11557 & 9.91 \\
Praseodymium & 9900 & 8.49 \\
Neodymium & 28463 & 24.41 \\
Samarium & 6727 & 5.77 \\
Europium & 6918 & 5.93 \\
Gadolinium & 4885 & 4.19 \\
& & \\
Aluminum & 297 & 0.25 \\
Calcium & 18 & 0.02 \\
Chromium & 107 & 0.09 \\
Iron & 1315 & 1.13 \\
Potassium & 59 & 0.05 \\
Manganese & 7175 & 6.15 \\
Sodium & 149 & 0.13 \\
Nickel & 78 & 0.07 \\
\hline Total & 98816 & 84.75 \\
\hline (a) Solution & &
\end{tabular}

(a) Solution concentrations based on a 1,166 L volume

The surrogate solution was prepared in the same manner as the simulated Tank 17.1 solution. Equal molar concentrations of europium, gadolinium, and iron were used as the surrogates for $\mathrm{Am} / \mathrm{Cm}$ and chromium, respectively. The solution was prepared by initially dissolving the target amounts of nonradioactive nitrate salts in $1 \mathrm{M}$ nitric acid, transferring the solution to a $1 \mathrm{~L}$ volumetric flask, and filling the flask with $1 \mathrm{M}$ nitric acid. A summary of the starting materials used to prepare the solution, the target and actual masses of reagents, and the final concentrations is provided in Appendix A. The additions of plutonium and uranium were made to a $500 \mathrm{~mL}$ 
volume of the nonradioactive solution. Uranium was added as UNH and plutonium as a measured aliquot of a nitrate solution containing $85 \mathrm{~g} / \mathrm{L}$ plutonium. The concentration of plutonium in the simulated solution was based on the results from the pretreatment solubility experiment. The concentrations of uranium and plutonium in the surrogate are given in Appendix A.

A simulation of the feed preparation step for the batch vitrification flowsheet was performed using the same laboratory equipment as the pretreatment solubility experiment (see Figure 3). Initially, a $250 \mathrm{~mL}$ aliquot of the pretreated $\mathrm{Am} / \mathrm{Cm}$ simulant was added to the precipitation flask. The solution was heated to $60^{\circ} \mathrm{C}$ and stirred using the hot plate and magnetic stirring bar. An oxalate precipitation was performed by adding $445 \mathrm{~mL}$ of $0.9 \mathrm{M}$ oxalic acid over approximately $20 \mathrm{~min}$. The excess oxalic acid concentration was $0.3 \mathrm{M}$ based on the prepared concentrations and complete precipitation of the lanthanide elements and plutonium. Once the oxalic acid addition was complete, the flask contents were cooled to $45^{\circ} \mathrm{C}$ (with continual stirring) and digested for $4 \mathrm{hr}$. Following the digestion, the flask contents were cooled to $35^{\circ} \mathrm{C}$ to simulate radiolytic heating and allowed to settle for $1 \mathrm{hr}$. Three $9.2 \mathrm{~mL}$ samples of the precipitation supernate were removed from the flask using a $10 \mathrm{~mL}$ disposable syringe. The solution was expelled through an $0.45 \mu \mathrm{m}$ filter disk into a small plastic sample bottle. To prevent precipitation of the lanthanide elements and plutonium, $2 \mathrm{~mL}$ of $15.7 \mathrm{M}$ nitric acid were transferred by pipette to the sample bottles before adding the precipitation supernate. Following sample removal a volume of supernate equal to the precipitant volume (minus the sample volume) was removed from the flask using the solution transfer system. After cooling overnight to $19^{\circ} \mathrm{C}$, a fine precipitate was present in the plastic storage bottle. Three additional samples of supernate were removed from the bottle to allow a comparison of solubility data at $35^{\circ} \mathrm{C}$.

To prepare for a single oxalic acid wash, the precipitate slurry was stirred and heated to $35^{\circ} \mathrm{C}$. A $250 \mathrm{~mL}$ aliquot of $0.1 \mathrm{M}$ oxalic acid was added to the flask using the addition funnel over approximately $20 \mathrm{~min}$. Once the addition was complete, the solution was stirred for an additional $15 \mathrm{~min}$ and allowed to settle for $1 \mathrm{hr}$. Three $9.2 \mathrm{~mL}$ samples of the wash solution supernate were removed from the flask using the sampling procedure discussed above. To prevent precipitation, $2 \mathrm{~mL}$ of $15.7 \mathrm{M}$ nitric acid were transferred by pipette to the bottles before adding the sample. After sampling, supernate was transferred from the flask using the solution transfer system leaving approximately $250 \mathrm{~mL}$ in the flask. After cooling overnight to $23^{\circ} \mathrm{C}$, a second set of 3 samples was removed from the transferred supernate which contained a fine precipitate on the bottom of the storage bottle.

In order to perform material balances for the lanthanide elements and plutonium, the oxalate precipitate generated during the simulated vitrification feed preparation was dissolved. The dissolution procedure for the precipitate was the same as employed for the precipitate generated during the pretreatment experiment. The dissolution process was initiated by adjusting the nitric acid concentration to nominally $8 \mathrm{M}$ by slowly adding a $250 \mathrm{~mL}$ aliquot of $15.7 \mathrm{M}$ nitric acid over approximately $1 \mathrm{hr}$, stirring, and heating at $65^{\circ} \mathrm{C}$. An air-cooled condenser was attached to the flask to reduce evaporation losses during heating. A $16 \mathrm{hr}$ oxalate digestion was performed before three $9.2 \mathrm{~mL}$ samples were removed from the precipitation flask. Following the extended 
digestion period, the solution appeared clear except for a small amount of solids which were assumed to be silica from the degradation of the glass precipitation vessel. However, the closure of a preliminary plutonium material balance was poor $(65 \%)$. Inspection of the storage bottle containing the digested solution revealed the presence of a red precipitate on the bottom. The solution and solids were transferred back to the precipitation flask to continue the oxalate digestion. A $1 \mathrm{~mL}$ aliquot of concentrated (28.9M) hydrofluoric acid was added to the flask to aid in the dissolution. The resulting fluoride concentration was nominally $0.065 \mathrm{M}$ based on the measured volume of solution. The flask was stirred and heated to $65^{\circ} \mathrm{C}$ for approximately $24 \mathrm{hr}$ over a 4 day period. During this time all solids dissolved. Three $9.4 \mathrm{~mL}$ samples were removed from the flask for analysis. The final volume of solution following sample removal was $407 \mathrm{~mL}$. A summary of the solution volumes added and removed from the precipitation flask during the feed preparation and dissolution processes is provided in Appendix B.

\section{$\underline{\text { Results and Discussion }}$}

The analytical results for the melter feed preparation experiment are summarized in Table 6 . The concentrations given in the table are the average results from the analysis of triplicate samples. The elemental analyses were performed using the same methods as described for the pretreatment experiment; however, interference problems were encountered with the ICP-ES analysis due to the high lanthanide concentrations. The data reported in Table 6 reflect the necessary dilutions made to prevent the precipitation of samples upon cooling.

Table 6 Oxalate Solubility Data for Melter Feed Preparation

Insoluble Oxalates

\begin{tabular}{|c|c|c|c|c|c|c|c|c|}
\hline & $\begin{array}{c}\mathrm{La} \\
(\mu \mathrm{g} / \mathrm{mL})\end{array}$ & $\begin{array}{c}\mathrm{Ce} \\
(\mu \mathrm{g} / \mathrm{mL})\end{array}$ & $\begin{array}{c}\mathrm{Pr} \\
(\mu \mathrm{g} / \mathrm{mL})\end{array}$ & $\begin{array}{c}\mathrm{Nd} \\
(\mu \mathrm{g} / \mathrm{mL})\end{array}$ & $\begin{array}{c}\mathrm{Sm} \\
(\mu \mathrm{g} / \mathrm{mL})\end{array}$ & $\begin{array}{c}\mathrm{Eu} \\
(\mu \mathrm{g} / \mathrm{mL})\end{array}$ & $\begin{array}{c}\mathrm{Gd} \\
(\mu \mathrm{g} / \mathrm{mL})\end{array}$ & $\begin{array}{c}\mathrm{Pu} \\
(\mu \mathrm{g} / \mathrm{mL})\end{array}$ \\
\hline \multicolumn{9}{|l|}{ Simulant } \\
\hline Makeup & 12580 & 9912 . & 8491 & 24411 & 5770 & 5933 & 4189 & 2040 \\
\hline Analysis & 12640 & 10508 & 8978 & 24382 & 6333 & 5790 & 4188 & 2138 \\
\hline \multicolumn{9}{|l|}{ Supernate } \\
\hline Analysis $\left(35^{\circ} \mathrm{C}\right)$ & 69 & 9.5 & 5.9 & 9.3 & $<2.3$ & 1.6 & 1.8 & 21 \\
\hline Analysis $\left(22.5^{\circ} \mathrm{C}\right)$ & 64 & 6.6 & 3.7 & 6.7 & $<2.3$ & 1.2 & 1.1 & 18 \\
\hline \multicolumn{9}{|l|}{ Oxalic Acid Wash } \\
\hline Analysis $\left(35^{\circ} \mathrm{C}\right)$ & 9.4 & 4.1 & 3.5 & 3.9 & $<2.3$ & 0.6 & 0.7 & 21 \\
\hline Analysis $\left(23^{\circ} \mathrm{C}\right)$ & 8.2 & $<3.20$ & $<1.5$ & $<1.6$ & $<2.3$ & 0.3 & $<0.4$ & 21 \\
\hline \multicolumn{9}{|l|}{ Melter Feed } \\
\hline Analysis & 6584 & 5458 & 4614 & 12962 & 3273 & 3031 & 2208 & 1099 \\
\hline Calculated $^{(\mathrm{a})}$ & 6744 & 5606 & 4790 & 13008 & 3379 & 3089 & 2234 & 1141 \\
\hline
\end{tabular}

(a) Calculated values assume $100 \%$ recovery. 
WSRC-TR-99-00162

Revision 0

Table 6 Continued

Soluble Oxalates

\begin{tabular}{|c|c|c|c|c|c|c|c|c|}
\hline & $\begin{array}{c}\mathrm{U} \\
(\mu \mathrm{g} / \mathrm{mL})\end{array}$ & $\begin{array}{c}\mathrm{Al} \\
(\mu \mathrm{g} / \mathrm{mL})\end{array}$ & $\begin{array}{c}\mathrm{Ca} \\
(\mu \mathrm{g} / \mathrm{mL})\end{array}$ & $\begin{array}{c}\mathrm{Fe} \\
(\mu \mathrm{g} / \mathrm{mL})\end{array}$ & $\underset{(\mu \mathrm{g} / \mathrm{mL})}{\mathrm{K}}$ & $\begin{array}{c}\mathrm{Mn} \\
(\mu \mathrm{g} / \mathrm{mL})\end{array}$ & $\underset{(\mu \mathrm{ga} / \mathrm{mL})}{\mathrm{Na}}$ & $\begin{array}{c}\mathrm{Ni} \\
(\mu \mathrm{g} / \mathrm{mL})\end{array}$ \\
\hline \multicolumn{9}{|l|}{ Simulant } \\
\hline Makeup & 142 & 254 & 15 & 1226 & 50 & 6153 & 128 & 67 \\
\hline Analysis & 160 & $752^{(b)}$ & $48^{(\mathrm{b})}$ & 1253 & 47 & 6286 & 175 & 97 \\
\hline \multicolumn{9}{|l|}{ Supernate } \\
\hline Analysis $\left(35^{\circ} \mathrm{C}\right)$ & 52 & 90 & 7.6 & 442 & 17 & 2255 & 47 & 30 \\
\hline Analysis $\left(22.5^{\circ} \mathrm{C}\right)$ & 49 & 89 & 7.6 & 441 & 17 & 2285 & 47 & 29 \\
\hline Calculated $^{(\mathrm{c})}$ & 58 & $91^{(\mathrm{d})}$ & $5.6^{(\mathrm{d})}$ & 451 & 17 & 2261 & 63 & 35 \\
\hline \multicolumn{9}{|l|}{ Oxalic Acid Wash } \\
\hline Analysis $\left(35^{\circ} \mathrm{C}\right)$ & 25 & 42 & 3.8 & 215 & 8.8 & 1104 & 23 & 15 \\
\hline Analysis $\left(23^{\circ} \mathrm{C}\right)$ & 24 & 44 & 3.9 & 222 & 8.2 & 1103 & 23 & 14 \\
\hline Calculated $^{(c)}$ & 28 & $45^{(\mathrm{d})}$ & $2.7^{(\mathrm{d})}$ & 222 & 8.3 & 1115 & 31 & 17 \\
\hline \multicolumn{9}{|l|}{ Feed } \\
\hline Analysis & 21 & $286^{(\mathrm{b})}$ & $18^{(\mathrm{b})}$ & 113 & 4.2 & 518 & 29 & 15 \\
\hline Calculated $^{(\mathrm{c})}$ & 15 & $24^{(\mathrm{d})}$ & $1.5^{(\mathrm{d})}$ & 119 & 4.4 & 598 & 17 & 9.2 \\
\hline
\end{tabular}

(b) Measured value biased high due to interferences with lanthanide elements.

(c) Calculated values assume complete solubility.

(d) Calculated using the element makeup concentration.

The concentration of each element in the pretreated $\mathrm{Am} / \mathrm{Cm}$ surrogate, calculated from the mass of the starting material (see Appendix A), is also presented in Table 6. The difference between the "makeup" and experimentally measured concentrations for the lanthanides and plutonium are in good agreement with the difference in the concentrations being less than $9 \%$ for all elements; although, the measured lanthanide concentrations do appear biased higher than the "makeup" concentrations. This observation is in contrast to the measured lanthanide concentrations in the simulant prepared for the pretreatment experiment which appeared biased lower than the "makeup" concentrations presumably due to the absorption of moisture by the nitrate salts. The high bias in the lanthanide concentrations for the pretreated $\mathrm{Am} / \mathrm{Cm}$ surrogate suggests that spectral interferences between these elements likely exists at high concentrations.

Spectral interferences also influenced the concentrations for several metal impurities. The concentrations of aluminum and calcium, and to a lesser extend sodium and nickel were high when compared to the "makeup" concentrations. To verify that interferences from the lanthanide elements contributed to the positive bias in these concentrations, a $10 \mathrm{~mL}$ sample of the pretreated $\mathrm{Am} / \mathrm{Cm}$ surrogate was precipitated with $25 \mathrm{~mL}$ of oxalic acid to remove the majority of the lanthanide elements from solution. Duplicate samples of the supernate were then analyzed 
by ICP-ES for the metal impurities (excluding uranium and potassium). Two samples of the untreated surrogate were also analyzed for sodium by AAS. The results from these analyses are compare with the "makeup" concentrations and the original analysis in Table 7.

Table 7 Analysis of Am/Cm Surrogate Following Oxalate Precipitation

\begin{tabular}{lccccccc}
\hline \hline & $\begin{array}{c}\mathrm{Al} \\
(\mu \mathrm{g} / \mathrm{mL})\end{array}$ & $\begin{array}{c}\mathrm{Ca} \\
(\mu \mathrm{g} / \mathrm{mL})\end{array}$ & $\begin{array}{c}\mathrm{Fe} \\
(\mu \mathrm{g} / \mathrm{mL})\end{array}$ & $\begin{array}{c}\mathrm{Mn} \\
(\mu \mathrm{g} / \mathrm{mL})\end{array}$ & $\begin{array}{c}\mathrm{Na} \\
(\mu \mathrm{g} / \mathrm{mL})\end{array}$ & $\begin{array}{c}\mathrm{Na} \\
(\mu \mathrm{g} / \mathrm{mL})\end{array}$ & $\begin{array}{c}\mathrm{Ni} \\
(\mu \mathrm{g} / \mathrm{mL})\end{array}$ \\
\hline Makeup & 254 & 15 & 1226 & 6153 & 128 & 128 & 67 \\
$1^{\text {st }}$ Analysis & 752 & 48 & 1253 & 6286 & $175^{(1)}$ & $\mathrm{N} / \mathrm{A}$ & 97 \\
$2^{\text {nd }}$ Analysis & 301 & 14 & 1288 & 5863 & $218^{(1)}$ & $199^{(2)}$ & 71. \\
\hline
\end{tabular}

(1) Analyzed by ICP-ES.

(2) Analyzed by AAS.

The elemental analysis of the treated sample clearly showed a reduction in the concentrations of aluminum, calcium, and nickel. Therefore, the positive bias in the original analyses can be at least partially attributed to spectral interferences due to the high lanthanide concentrations. The results from the sodium analyses were inconclusive. Neither analytical method showed the expected decrease in the sodium concentration suggesting there could be other problems with the analysis. The measured concentrations shown in Table 6 for all of the elements except aluminum and calcium were used for subsequent calculations presented in the table. For aluminum and calcium, the "makeup" concentrations were used for these calculations.

The solubility of the plutonium (IV) oxalate in the precipitation supernate was $21 \mu \mathrm{g} / \mathrm{mL}$ at $35^{\circ} \mathrm{C}$. This value is approximately a factor of 2 higher than the concentration measured in the precipitation supernate during the pretreatment solubility experiment. The difference in the measured concentration can be attributed to differences in the ionic strength of the solutions. The nitrate concentration in the pretreated $\mathrm{Am} / \mathrm{Cm}$ surrogate was much higher than the concentration in the Tank 17.1 simulant due to the high lanthanide concentrations. The higher nitrate concentration should increase the plutonium solubility due to increased complexation.

The relative solubilities for the lanthanide elements shown in Table 6 are consistent with the solubility measurements made during the pretreatment experiment and the Am/Cm pretreatment development program (see Figure 4); although, the actual values are less. The decrease in solubilities of the lanthanide oxalates compared to the solubilities measured during these experiments can be attributed to a decrease in the nitric acid concentration due to the dilution by the larger volume of oxalic acid required for precipitation. The effect of temperature on the solubility of the lanthanides and plutonium was not as pronounced as seen during the pretreatment experiment presumably due to the lower nitric acid concentration. 
Simulation of the melter feed preparation process provided an additional demonstration that uranium and the alkali, alkaline earth, and transition metal impurities in the Tank 17.1 solution are soluble in oxalic acid under these conditions. Table 6 provides a comparison of the measured and calculated concentrations for these elements at each step in the process assuming complete solubility. The measured and calculated values are in good agreement except for the elements where difficulties were encountered with the elemental analyses. As before, a decrease in temperature had no effect on the concentrations measured in the precipitation supernate or oxalic acid wash solution.

Using the concentrations given in Table 6 and the volumes of solution added and removed from the precipitation flask during the melter feed preparation experiment (reported in Appendix B), material balances were performed for each element in the pretreated $\mathrm{Am} / \mathrm{Cm}$ simulant. For each element, the percentage of the mass recovered following dissolution of the oxalate precipitate and the percentages lost to the precipitation supernate and wash solutions are given in Table 8 . The material balance closure for each element, calculated as the percentage of the element in the pretreated $\mathrm{Am} / \mathrm{Cm}$ simulant, is also given in the table. For the plutonium material balance, it was necessary to use the concentrations measured in the dissolved precipitate following the second digestion to obtain good material balance closure. For the other elements in the simulant, the closure did not improve when the analyses from the second set of dissolved precipitate samples were used to perform the material balance, indicating the red solids observed in the storage bottle where most likely a plutonium oxalate. A plutonium (IV) oxalate dihydrate has been precipitated by the addition of $10 \%$ oxalic acid to a solution of plutonium in $7 \mathrm{M}$ nitric acid at elevated temperature $\left(50\right.$ or $\left.75^{\circ} \mathrm{C}\right) \cdot[6]$

The material balances for the lanthanide elements and plutonium showed minimal solubility losses during the oxalate precipitation and wash steps used to simulate the preparation of feed for a batch melter. Greater than $99 \%$ of the europium and gadolinium, the surrogates for $\mathrm{Am} / \mathrm{Cm}$, were recovered during the solubility experiment. The recovery of plutonium during the simulated feed preparation was greater than $97 \%$ leading to an estimate that nominally $92 \%$ of the plutonium in Tank 17.1 will report to the glass. This estimate takes into account the solubility losses during the pretreatment and melter feed preparation, but, does not include any estimate of material loss during the transfer of solution during these processes.

The closure of the material balances for several of the alkali, alkaline earth, and transition metal impurities (see Table 8) were much poorer than the closure of material balances for the simulated pretreatment process. The poor closure was attributed to problems encountered during the analysis of these elements in the pretreated $\mathrm{Am} / \mathrm{Cm}$ surrogate and the dissolved oxalate precipitate. The recovery of the soluble oxalates ranged from approximately 14 to $29 \%$. Based on the dilution effects and the volumes of supernate and wash solution removed during the experiment, the theoretical recovery was nominally $18 \%$. Of the $82 \%$ of the soluble oxalates theoretically removed during the melter feed preparation, $65 \%$ were removed in the precipitation supernate, and $17 \%$ were removed in the oxalic acid wash solution. 
Table 8 Material Balances for Melter Feed Preparation Insoluble Oxalates

\begin{tabular}{lcccccccc}
\hline \hline & $\begin{array}{c}\mathrm{La} \\
(\%)\end{array}$ & $\begin{array}{c}\mathrm{Ce} \\
(\%)\end{array}$ & $\begin{array}{c}\mathrm{Pr} \\
(\%)\end{array}$ & $\begin{array}{c}\mathrm{Nd} \\
(\%)\end{array}$ & $\begin{array}{c}\mathrm{Sm} \\
(\%)\end{array}$ & $\begin{array}{c}\mathrm{Eu} \\
(\%)\end{array}$ & $\begin{array}{c}\mathrm{Gd} \\
(\%)\end{array}$ & $\begin{array}{c}\mathrm{Pu} \\
(\%)\end{array}$ \\
\hline Element Recovered & 98.9 & 99.8 & 99.8 & 99.9 & 100.0 & 99.9 & 99.9 & 97.3 \\
& & & & & & & & \\
Element Lost & 1.1 & 0.2 & 0.2 & 0.1 & 0.0 & 0.1 & 0.1 & 2.7 \\
$\quad \begin{array}{l}\text { Precipitation Supernate } \\
\quad \text { Oxalic Acid Wash }\end{array}$ & 1.0 & 0.2 & 0.1 & 0.1 & 0.0 & 0.1 & 0.1 & 1.8 \\
& 0.1 & 0.0 & 0.0 & 0.0 & 0.0 & 0.0 & 0.0 & 0.9 \\
Material Balance Closure & 98.7 & 97.5 & 96.5 & 99.7 & 96.9 & 98.2 & 98.9 & 97.8 \\
\hline
\end{tabular}

Soluble Oxalates

\begin{tabular}{lcccccccc}
\hline \hline & $\mathrm{U}$ & $\mathrm{Al}$ & $\mathrm{Ca}$ & $\mathrm{Fe}$ & $\mathrm{K}$ & $\mathrm{Mn}$ & $\mathrm{Na}$ & $\mathrm{Ni}$ \\
& $(\%)$ & $(\%)$ & $(\%)$ & $(\%)$ & $\begin{array}{c}(\%) \\
(\%)\end{array}$ & $\begin{array}{c}(\%) \\
(\%)\end{array}$ \\
\hline Element Recovered & 24.7 & 18.3 & 13.7 & 17.4 & 16.4 & 15.9 & 33.9 & 28.7 \\
& & & & & & & & \\
Element Lost & 75.3 & 81.7 & 86.3 & 82.6 & 83.6 & 84.1 & 66.1 & 71.3 \\
$\quad$ Precipitation Supernate & 59.9 & 65.4 & 67.9 & 65.5 & 65.8 & 66.6 & 52.4 & 56.5 \\
$\quad$ Oxalic Acid Wash & 15.3 & 16.4 & 18.5 & 17.1 & 17.7 & 17.5 & 13.7 & 14.8 \\
& & & & & & & & \\
Material Balance Closure & 97.8 & 97.5 & 130.4 & 97.3 & 102.5 & 97.3 & 92.4 & 98.0 \\
\hline
\end{tabular}

An americium material balance was also performed for the melter feed preparation experiment using the americium-241 produced from the beta decay of plutonium-241. Table 9 provides a summary of the americium mass in the pretreated $\mathrm{Am} / \mathrm{Cm}$ surrogate, the amounts recovered and lost during the melter feed preparation, and the results from the material balance. The amount of americium recovered in the dissolved precipitate is in excellent agreement with the recovery of europium (the americium surrogate) demonstrated by the material balances in Tables 8 and 9 . The overall recovery of americium, predicted by the trace level material balances, for the $\mathrm{Am} / \mathrm{Cm}$ pretreatment and melter feed preparation processes was greater than $97 \%$. As with plutonium, this estimate takes into account the solubility losses, but, does not include any estimate of material loss during the transfer of solution during these processes. 
Table 9 Americium Material Balance for Melter Feed Preparation

\begin{tabular}{lcc}
\hline \hline & $\begin{array}{c}\text { Mass } \\
(\mathrm{mg})\end{array}$ & $\begin{array}{c}\text { Total } \\
(\%)\end{array}$ \\
\hline Americium in Simulant & $1.81 \times 10^{-4}$ & \\
Americium Recovered & $1.81 \times 10^{-4}$ & 99.9 \\
& & \\
Americium Lost & $2.70 \times 10^{-7}$ & 0.1 \\
$\quad$ Precipitation Supernate & $2.05 \times 10^{-7}$ & 0.1 \\
$\quad$ Oxalic Acid & $6.46 \times 10^{-8}$ & 0.0 \\
Material Balance Closure & & 100.0 \\
\hline
\end{tabular}




\section{Conclusions}

The pretreatment process planned for preparing the Tank $17.1 \mathrm{Am} / \mathrm{Cm}$ solution for vitrification was simulated to measure the solubility of plutonium (IV) oxalate during the processing steps. An oxalate precipitation was initially performed using a simulated solution with europium and gadolinium present as surrogates for the $A m / C m$. The plutonium (IV) oxalate solubility in the precipitation supernate was $10 \mu \mathrm{g} / \mathrm{mL}$ (at $35^{\circ} \mathrm{C}$ ). In subsequent precipitate washing steps using $0.25 \mathrm{M}$ oxalic acid $/ 0.5 \mathrm{M}$ nitric acid, the solubility dropped to less than $5 \mu \mathrm{g} / \mathrm{mL}$. During the precipitation and washing steps, the behavior of the lanthanides, uranium, and alkali, alkaline earth, and transition metal impurities was predictable. The lanthanide oxalates were mostly insoluble with the solubility generally decreasing with increasing atomic number. Uranium and the alkali, alkaline earth, and transition metal impurities were soluble throughout the pretreatment process. The concentration of these elements were accurately predicted using the simulant concentration and volumes of reagents added and supernate removed from the precipitation vessel.

Following the precipitation washing steps, the oxalate precipitate was dissolved allowing elemental material balances to be performed for the pretreatment process. Greater than $94 \%$ of the plutonium was recovered in the dissolved precipitate. The recoveries of the lanthanide oxalates were generally $94 \%$ or higher except for lanthanum for which the recovery was only $84 \%$ due to the higher solubility of its oxalate salt. The recovery of uranium and the alkali, alkaline earth, and transition metal impurities ranged from 15 to $22 \%$. Based on the dilution effects and the volumes of supernate and wash solutions removed during the experiment, the theoretical recovery was $16 \%$. A trace level material balance was also performed for americium using the americium-241 daughter from the decay of plutonium-241. Greater than $97 \%$ of the americium was recovered in the dissolved precipitate which is consistent with the recovery of europium, the surrogate for americium in the simulated solution. The material balance closure was very good for all elements.

In a subsequent experiment, the solubility of plutonium (IV) oxalate was measured during a simulation of the flowsheet for preparation of an oxalate slurry feed for vitrification of the pretreated $\mathrm{Am} / \mathrm{Cm}$. The measured solubility following an oxalate precipitation of the surrogate solution was $21 \mu \mathrm{g} / \mathrm{mL}$ (at $35^{\circ} \mathrm{C}$ ). The increase in solubility compared to the value measured during the pretreatment experiment $(10 \mu \mathrm{g} / \mathrm{mL})$ was attributed to the increased nitrate concentration and ensuing increase in plutonium complexation. The solubility of the plutonium following a precipitant wash with $0.1 \mathrm{M}$ oxalic acid was unchanged. The solubility of the lanthanide elements decreased in both the precipitation supernate and wash solution compared to values measured during the pretreatment experiment. The lower solubilities were primarily due to a decrease in the nitric acid concentration as result of the increased volume of oxalic acid required for the precipitation. Uranium and the alkali, alkaline earth, and transition metal impurities were soluble during the simulated feed preparation as expected. 
Dissolution of the oxalate precipitate following preparation of the simulated melter feed allowed the performance of elemental material balances. The recovery of plutonium from the precipitate slurry was greater than $97 \%$ allowing an estimation that approximately $92 \%$ of the plutonium in Tank 17.1 will report to the glass. Greater than $99 \%$ of the lanthanide elements in the pretreated surrogate were recovered from the precipitate slurry. Material balances for uranium and the alkali, alkaline earth, and transition metal impurities showed recoveries of these elements ranging from 14 to $29 \%$. The theoretical recovery, based on the solubility, dilution effects, and volumes of supernate and wash solution removed during the experiment, was approximately $18 \%$. The difference between the measured and theoretical values was the result of problems with the elemental analyses, primarily due to spectral interferences from the high lanthanide concentrations. An americium material balance performed using gamma pulse height analyses for americium-241 showed the recovery of greater than $99.9 \%$ of the americium from the precipitate slurry. This value was consistent with the recovery of europium, the surrogate for americium, during the simulation. The overall recovery of americium from the pretreatment and feed preparation processes was greater than $97 \%$, a value also consistent with the measured europium recovery. 


\section{References}

1. J. T. Conway, "Recommendation 94-1 to the Secretary of Energy pursuant to 42 U.S.C. [paragraph] 2286a(5) Atomic Energy Act of 1954, as amended" (Attachment), Letter from Defense Nuclear Facilities Safety Board to Secretary of Energy, Washington, DC (1994).

2. L. Gmelin, Gmelin Handbuch der Anorganischen Chemie, Band 20, Teil D1: Chemie in Lösung, Springer-Veriag, New York, NY (1975).

3. Code of Federal Regulations, Title 10-Energy, Part 71-Packaging and Transportation of Radioactive Material, Subpart B-Exemptions, page 235, revised January 1, 1998.

4. T. S. Rudisill, Pretreatment of Americium/Curium Solutions for Vitrification, Report WSRCTR-96-0074, Westinghouse Savannah River Company, Aiken, SC (March 1996).

5. J. J. Katz, G. T. Seaborg, and L. R. Morss, Editors, The Chemistry of the Actinide Elements, $2^{\text {nd }}$ Edition, Volume 2, Chapman and Hall Ltd., New York, NY (1986).

6. J. M. Cleveland, The Chemistry of Plutonium, American Nuclear Society, La Grange Park, IL (1979). 
This page was intentionally left blank. 
WSRC-TR-99-00162

Revision 0

Figure $1 \mathrm{Am} / \mathrm{Cm}$ Pretreatment in F-Canyon

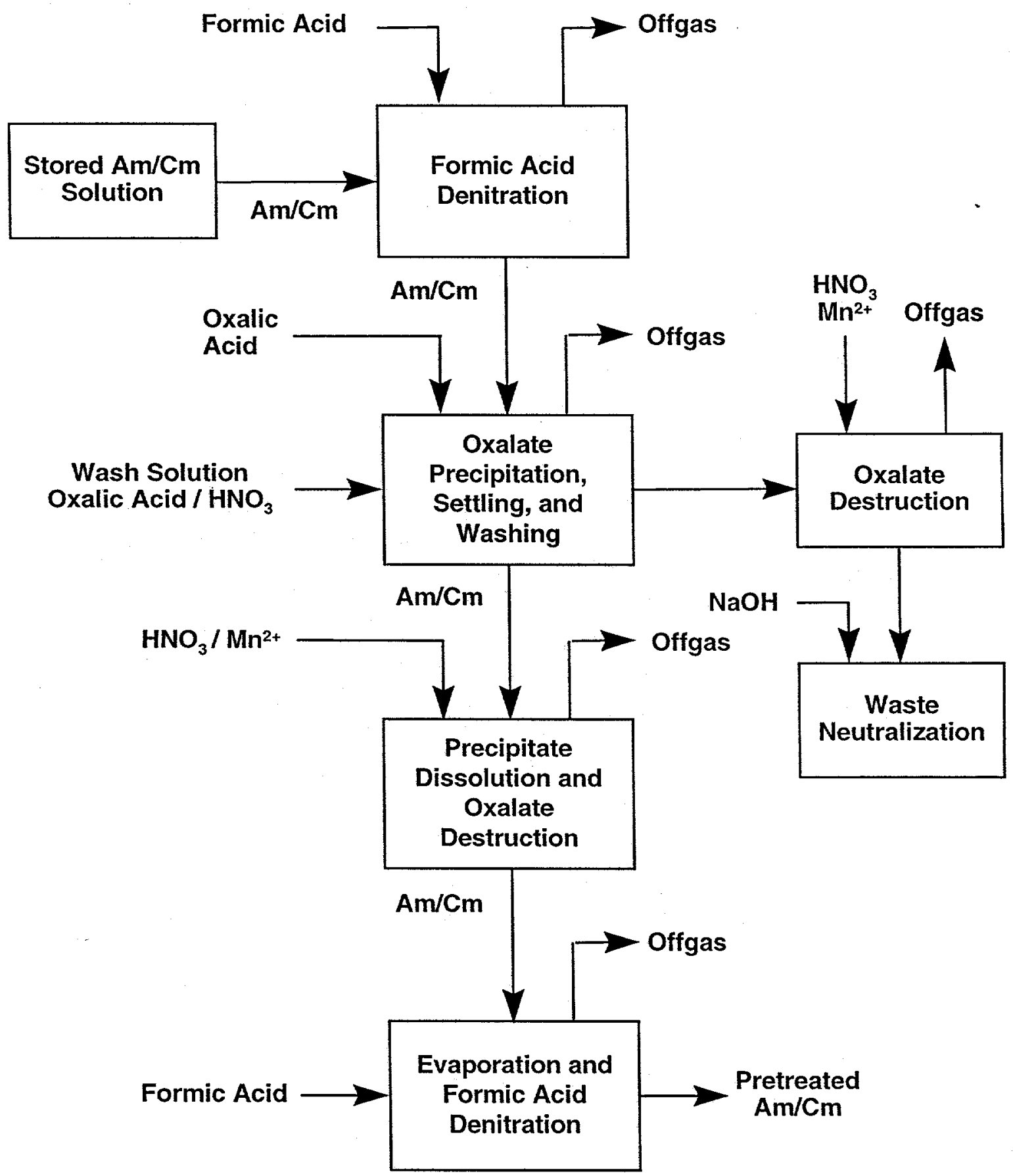




\section{This page was intentionally left blank.}


Figure 2 Solubility of Plutonium (IV) Oxalate

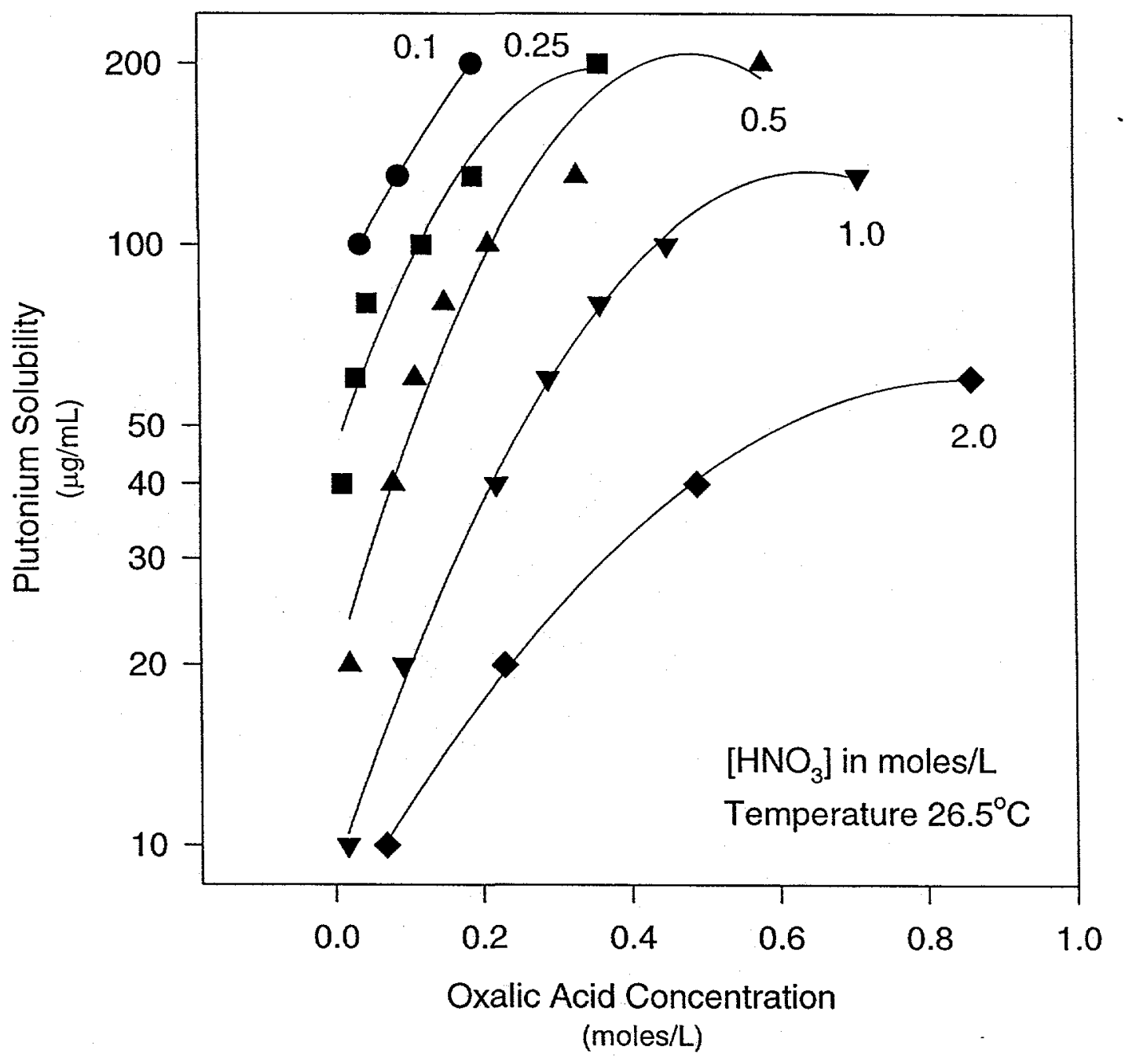




\section{This page was intentionally left blank.}


Figure 3 Precipitation Equipment

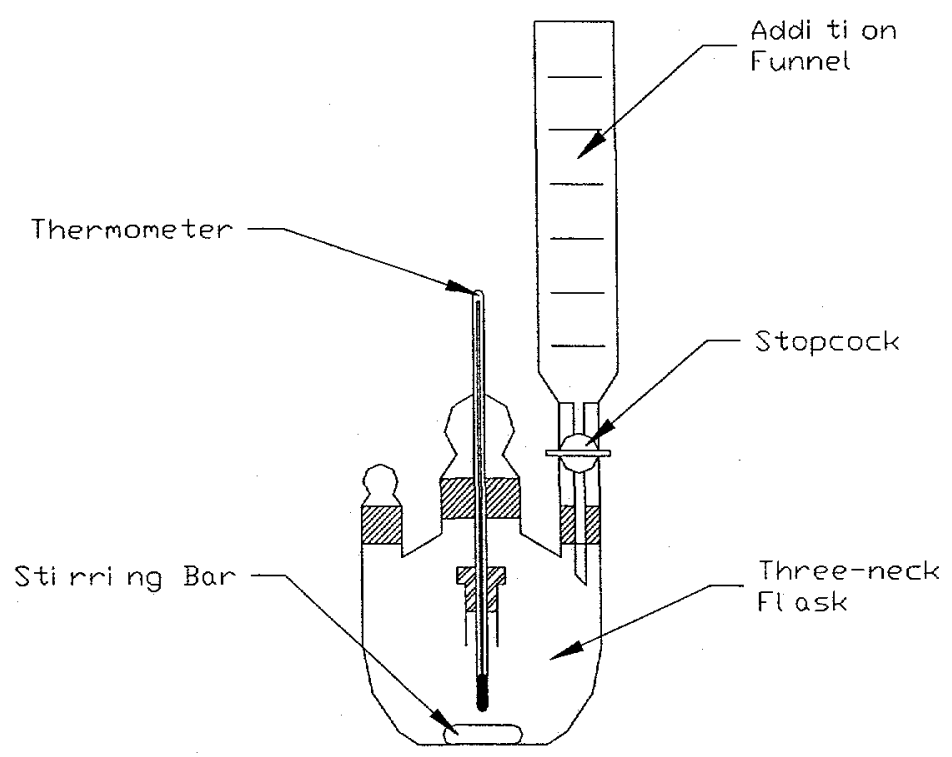

Precipitation Vessel

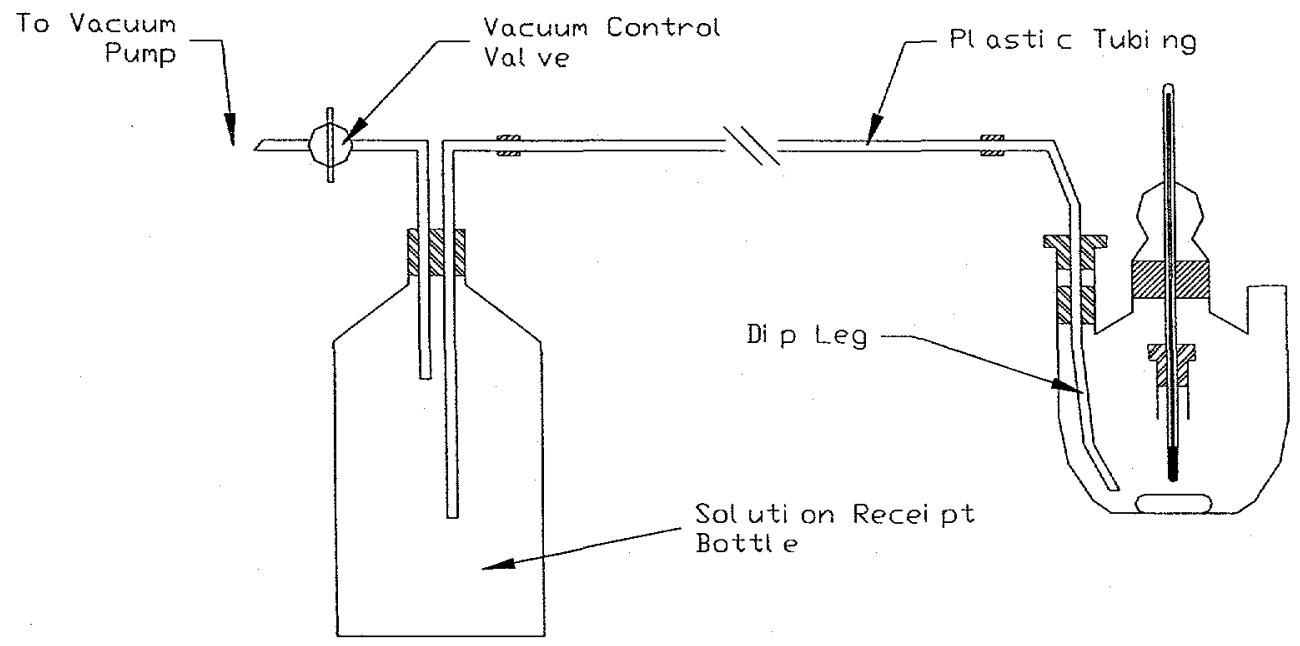

Solution Transfer Equipment 
WSRC-TR-99-00162

Revision 0

\section{This page was intentionally left blank.}


Figure 4 Solubility of Lanthanide Oxalates[4]

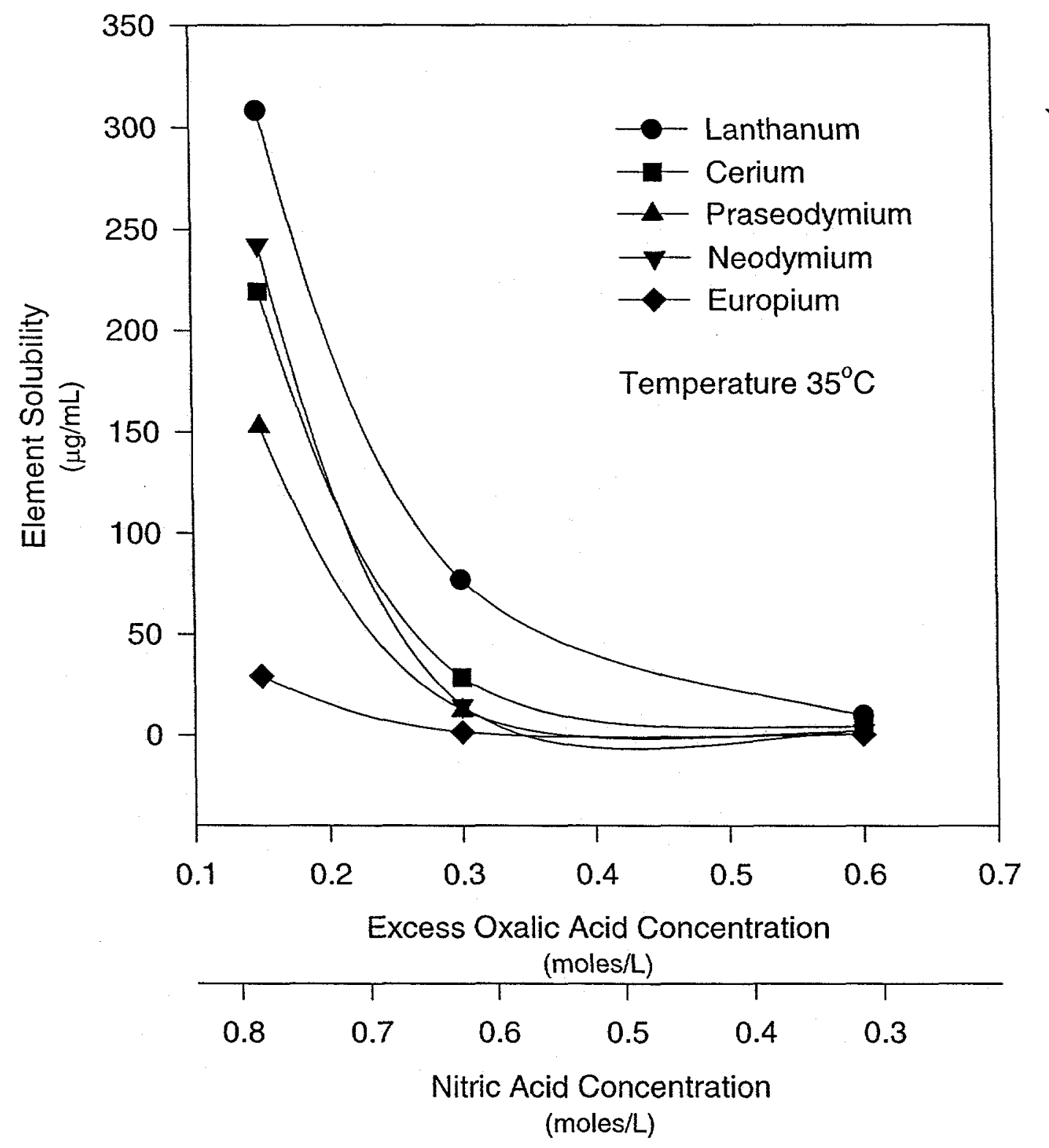


WSRC-TR-99-00162

Revision 0

\section{This page was intentionally left blank.}




\section{Appendix A Preparation of Simulated Solutions}

Table A.1 Simulated Tank 17.1 Solution

\begin{tabular}{|c|c|c|c|c|}
\hline Element & $\begin{array}{l}\text { Nitrate Salt } \\
\text { Starting } \\
\text { Material }\end{array}$ & $\begin{array}{c}\text { Target Mass } \\
\text { Starting } \\
\text { Material } \\
(\mathrm{g}) \\
\end{array}$ & $\begin{array}{l}\text { Actual Mass } \\
\text { Starting } \\
\text { Material } \\
\text { (g) } \\
\end{array}$ & $\begin{array}{c}\text { Element } \\
\text { Concentration } \\
(\mathrm{g} / \mathrm{L}) \\
\end{array}$ \\
\hline Lanthanum (La) & $\mathrm{La}\left(\mathrm{NO}_{3}\right)_{3} \cdot 6 \mathrm{H}_{2} \mathrm{O}$ & 3.0695 & 3.0650 & 0.983 \\
\hline Cerium $(\mathrm{Ce})$ & $\mathrm{Ce}\left(\mathrm{NO}_{3}\right)_{3} \cdot 6 \mathrm{H}_{2} \mathrm{O}$ & 2.3986 & 2.3957 & 0.773 \\
\hline Praseodymium (Pr) & $\operatorname{Pr}\left(\mathrm{NO}_{3}\right)_{3} \cdot 6 \mathrm{H}_{2} \mathrm{O}$ & 2.0413 & 2.0418 & 0.661 \\
\hline Neodymium (Nd) & $\mathrm{Nd}\left(\mathrm{NO}_{3}\right)_{3} \cdot 6 \mathrm{H}_{2} \mathrm{O}$ & 5.7721 & 5.7734 & 1.900 \\
\hline Samarium $(\mathrm{Sm})$ & $\mathrm{Sm}\left(\mathrm{NO}_{3}\right)_{3} \cdot 6 \mathrm{H}_{2} \mathrm{O}$ & 1.3308 & 1.3339 & 0.451 \\
\hline Europium (Eu) & $\mathrm{Eu}\left(\mathrm{NO}_{3}\right)_{3} \cdot 5 \mathrm{H}_{2} \mathrm{O}$ & 1.3051 & 1.3050 & 0.463 \\
\hline Gadolinium (Gd) & $\mathrm{Gd}\left(\mathrm{NO}_{3}\right)_{3} \cdot 6 \mathrm{H}_{2} \mathrm{O}$ & 0.9381 & 0.9343 & 0.326 \\
\hline Aluminum (Al) & $\mathrm{Al}\left(\mathrm{NO}_{3}\right)_{3} \cdot 9 \mathrm{H}_{2} \mathrm{O}$ & 15.2103 & 15.2124 & 1.094 \\
\hline Calcium (Ca) & $\mathrm{Ca}\left(\mathrm{NO}_{3}\right)_{2} \cdot 4 \mathrm{H}_{2} \mathrm{O}$ & 0.3924 & 0.3936 & 0.067 \\
\hline Iron $(\mathrm{Fe})$ & $\mathrm{Fe}\left(\mathrm{NO}_{3}\right)_{3} \cdot 9 \mathrm{H}_{2} \mathrm{O}$ & 38.1700 & 38.1768 & 5.277 \\
\hline Potassium (K) & $\mathrm{KNO}_{3}$ & 0.5611 & 0.5662 & 0.219 \\
\hline Manganese (Mn) & $\mathrm{Mn}\left(\mathrm{NO}_{3}\right)_{2} \cdot 6 \mathrm{H}_{2} \mathrm{O}$ & 1.2682 & 1.269 & 0.243 \\
\hline Sodium $(\mathrm{Na})$ & $\mathrm{NaNO}_{3}$ & 2.0314 & 2.0397 & 0.552 \\
\hline Nickel (Ni) & $\mathrm{Ni}\left(\mathrm{NO}_{3}\right)_{2} \cdot 6 \mathrm{H}_{2} \mathrm{O}$ & 1.4289 & 1.4289 & 0.288 \\
\hline Uranium $(U)$ & $\mathrm{UO}_{2}\left(\mathrm{NO}_{3}\right)_{2} \cdot 6 \mathrm{H}_{2} \mathrm{O}$ & $0.6437^{(\mathrm{a})}$ & $0.6457^{(\mathrm{a})}$ & 0.612 \\
\hline Plutonium $(\mathrm{Pu})$ & $\mathrm{Pu}^{4+}(\mathrm{aq})$ & $0.0794^{(\mathrm{b})}$ & $0.102^{(\mathrm{c})}$ & 0.204 \\
\hline Total & & & & 14.113 \\
\hline
\end{tabular}

(a) Mass of UNH to prepare $500 \mathrm{~mL}$ of surrogate solution

(b) Mass of plutonium required to prepare $500 \mathrm{~mL}$ of surrogate solution

(c) Mass of plutonium from $3 \mathrm{~mL}$ of a $34 \mathrm{~g} / \mathrm{L}$ solution added to surrogate solution 
WSRC-TR-99-00162

Revision 0

Table A.2 Simulated Feed Solution for Am/Cm Vitrification

\begin{tabular}{|c|c|c|c|c|}
\hline Element & $\begin{array}{l}\text { Nitrate Salt } \\
\text { Starting } \\
\text { Material }\end{array}$ & $\begin{array}{c}\text { Target Mass } \\
\text { Starting } \\
\text { Material } \\
\text { (g) } \\
\end{array}$ & $\begin{array}{c}\text { Actual Mass } \\
\text { Starting } \\
\text { Material } \\
\text { (g) }\end{array}$ & $\begin{array}{c}\text { Element } \\
\text { Concentration } \\
(\mathrm{g} / \mathrm{L})\end{array}$ \\
\hline Lanthanum & $\mathrm{La}\left(\mathrm{NO}_{3}\right)_{3} \cdot 6 \mathrm{H}_{2} \mathrm{O}$ & 39.2144 & 39.2153 & 12.58 \\
\hline Cerium & $\mathrm{Ce}\left(\mathrm{NO}_{3}\right)_{3} \cdot 6 \mathrm{H}_{2} \mathrm{O}$ & 30.7166 & 30.7613 & 9.93 \\
\hline Praseodymium & $\operatorname{Pr}\left(\mathrm{NO}_{3}\right)_{3} \cdot 6 \mathrm{H}_{2} \mathrm{O}$ & 26.2133 & 26.2226 & 8.49 \\
\hline Neodymium & $\mathrm{Nd}\left(\mathrm{NO}_{3}\right)_{3} \cdot 6 \mathrm{H}_{2} \mathrm{O}$ & 74.1853 & 74.1864 & 24.41 \\
\hline Samarium & $\mathrm{Sm}\left(\mathrm{NO}_{3}\right)_{3} \bullet 6 \mathrm{H}_{2} \mathrm{O}$ & 17.0551 & 17.0549 & 5.77 \\
\hline Europium & $\mathrm{Eu}\left(\mathrm{NO}_{3}\right)_{3} \cdot 5 \mathrm{H}_{2} \mathrm{O}$ & 16.7118 & 16.7113 & 5.93 \\
\hline Gadolinium & $\mathrm{Gd}\left(\mathrm{NO}_{3}\right)_{3} \cdot 6 \mathrm{H}_{2} \mathrm{O}$ & 12.0242 & 12.0259 & 4.19 \\
\hline Aluminum & $\mathrm{Al}\left(\mathrm{NO}_{3}\right)_{3} \bullet 9 \mathrm{H}_{2} \mathrm{O}$ & 3.5356 & 3.5458 & 0.26 \\
\hline Calcium & $\mathrm{Ca}\left(\mathrm{NO}_{3}\right)_{2} \bullet 4 \mathrm{H}_{2} \mathrm{O}$ & 0.0912 & 0.0954 & 0.02 \\
\hline Iron & $\mathrm{Fe}\left(\mathrm{NO}_{3}\right)_{3} \cdot 9 \mathrm{H}_{2} \mathrm{O}$ & 8.8715 & 8.8913 & 1.23 \\
\hline Potassium & $\mathrm{KNO}_{3}$ & 0.1304 & 0.1315 & 0.05 \\
\hline Manganese & $\mathrm{Mn}\left(\mathrm{NO}_{3}\right)_{2} \bullet 6 \mathrm{H}_{2} \mathrm{O}$ & 32.1496 & 32.148 & 6.15 \\
\hline Sodium & $\mathrm{NaNO}_{3}$ & 0.4721 & 0.4743 & 0.13 \\
\hline Nickel & $\mathrm{Ni}\left(\mathrm{NO}_{3}\right)_{2} \cdot 6 \mathrm{H}_{2} \mathrm{O}$ & 0.3320 & 0.3086 & 0.06 \\
\hline Uranium & $\mathrm{UO}_{2}\left(\mathrm{NO}_{3}\right)_{2} \cdot 6 \mathrm{H}_{2} \mathrm{O}$ & $0.1496^{(a)}$ & $0.15^{(a)}$ & 0.14 \\
\hline Plutonium & $\mathrm{Pu}^{4+}{ }_{(\mathrm{aq})}$ & $0.9598^{(b)}$ & $1.02^{(\mathrm{c})}$ & 2.04 \\
\hline
\end{tabular}

(a) Mass of UNH to prepare $500 \mathrm{~mL}$ of surrogate solution

(b) Mass of plutonium required to prepare $500 \mathrm{~mL}$ of surrogate solution

(c) Mass of plutonium from $12 \mathrm{~mL}$ of an $85 \mathrm{~g} / \mathrm{L}$ solution added to surrogate solution 
WSRC-TR-99-00162

Revision 0

\section{Appendix B Reagent Addition and Removal During Solubility Experiments}

Table B.1 Solution Volumes for Am/Cm Pretreatment

\begin{tabular}{|c|c|c|c|}
\hline \multicolumn{2}{|c|}{ Oxalate Precipitation } & \multicolumn{2}{|l|}{$1^{\text {st }}$ Wash } \\
\hline Solution & $\begin{array}{l}\text { Volume } \\
\text { (mL) }\end{array}$ & Solution & $\begin{array}{c}\text { Volume } \\
\text { (mL) }\end{array}$ \\
\hline Tank 17.1 Simulant & 250 & Initial Volume & 253 \\
\hline Oxalic Acid & 150 & Wash Solution & 250 \\
\hline Samples Removed & 56 & Samples Removed & 56 \\
\hline Solution Transferred & 91 & Solution Transferred & 201 . \\
\hline Total Solution Removed & 147 & Total Solution Removed & 257 \\
\hline Volume Remaining & 253 & Volume Remaining & 245 \\
\hline \multicolumn{2}{|l|}{$2^{\text {nd }}$ Wash } & \multicolumn{2}{|c|}{ Precipitate Dissolution } \\
\hline Solution & $\begin{array}{c}\text { Volume } \\
(\mathrm{mL})\end{array}$ & Solution & $\begin{array}{c}\text { Volume } \\
(\mathrm{mL})\end{array}$ \\
\hline Initial Volume & 245 & Initial Volume & 253 \\
\hline Wash Solution & 250 & Acid Addition & 250 \\
\hline Samples Removed & 56 & Samples Removed & 28 \\
\hline Solution Transferred & 175 & & \\
\hline Total Solution Removed & 231 & Total Solution Removed & 28 \\
\hline Volume Remaining & 264 & Volume Remaining & $486^{(a)}$ \\
\hline
\end{tabular}

(a) The measured volume of solution was $452 \mathrm{~mL}$; the missing solution was attributed to evaporation losses. 
Table B.2 Solution Volumes for Vitrification Feed Preparation

\begin{tabular}{lc}
\hline \hline \multicolumn{2}{c}{ Oxalate Precipitation } \\
Solution & $\begin{array}{c}\text { Volume } \\
(\mathrm{mL})\end{array}$ \\
\hline Pretreated Simulant & 250 \\
Oxalic Acid & 445 \\
Samples Removed(a) & 28 \\
Solution Transferred & 424 \\
& \\
Total Solution Removed & 452 \\
Volume Remaining & 243 \\
\hline
\end{tabular}

\begin{tabular}{lc}
\hline \hline Oxalic Acid Wash & $\begin{array}{c}\text { Volume } \\
\text { (mL) }\end{array}$ \\
\hline Initial Volume & 243 \\
Wash Solution & 250 \\
Samples Removed & 55 \\
Solution Transferred & 187 \\
& \\
Total Solution Removed & 242 \\
Volume Remaining & 251 \\
\hline
\end{tabular}

\begin{tabular}{lc}
\hline \hline \multicolumn{1}{c}{$1^{\text {st }}$ Precipitate Dissolution } \\
Solution & $\begin{array}{c}\text { Volume } \\
(\mathrm{mL})\end{array}$ \\
\hline Initial Volume & 251 \\
Acid Addition & 250 \\
Samples Removed & 28
\end{tabular}

\begin{tabular}{lc}
\hline \multicolumn{2}{c}{$2^{\text {nd }}$ Precipitate Dissolution } \\
Solution & $\begin{array}{c}\text { Volume } \\
(\mathrm{mL})\end{array}$ \\
\hline Initial Volume & 441 \\
Acid Addition & 1 \\
Samples Removed & 28 \\
& \\
Total Solution Removed & 28 \\
Volume Remaining & $414^{(\mathrm{c})}$ \\
\hline
\end{tabular}

Total Solution Removed

28

Volume Remaining

$474^{(b)}$

Volume Remaining

(a) Six samples were removed; however, 3 were removed following measurement of the supernate volume.

(b) The measured volume of solution was $441 \mathrm{~mL}$; the missing solution was attributed to evaporation losses.

(c) The measured volume of solution was $407 \mathrm{~mL}$; the missing solution was attributed to evaporation losses. 